\title{
Research on the Logistics Cost and Enterprise Operation Efficiency with the Influences on International Trade
}

\author{
Yuan Lin \\ Weihai Vocational College, \\ Weihai,Shandong,264210 China
}

\begin{abstract}
In this paper, we conduct research on the logistics cost and enterprise operation efficiency with the influences on international trade. With the deepening of the reform of the market economic system in our country, and the advancement of the reform of state-owned enterprises and government function transformation, the company is out of the shackles of the planned economy as the main body of market competition, at the same time, government regulators and investors in a state-owned capital market, all kinds of financial intermediaries and the information intermediary organizations, as well as the associated with the interests of closely linked to the enterprise value creation main body, including business owners and operators have yet to establish a timely to adapt to the market economy system. With this guidance, we propose the novel international trade paradigm for the companies that will enhance the efficiency of the general management.
\end{abstract}

Keywords- Logistics Cost, Enterprise, Operation Efficiency, International Trade, Influences.

\section{Introduction}

The essence of economic globalization is the international industrial structure adjustment, therefore, a country's industrial structure optimization, industrial structure also means that one country can adapt to the requirement of the industry development of globalization that can obtain more countries in the international industry market economic interests and realize its industrial structure system and the coordination of the industrial structure. In the new century international trade is affected by the new technology is bigger, the new technology, especially the electronic science and technology more and more influence on international trade development blocks today's international trade was a complete with associated new technologies. With the rapid development of multinational companies, the world of commodity production and circulation pattern changes constantly and become the important factors affecting international trade. Social consumer demands to general diversification development become another factors influence the international trade to promote trade between industries internal trade and industry is further development [1-3].

According to the literature review, the development of the international trade theory could be listed as the follows. (1) The classical trade theory. A country as long as the products specializing in the production of its absolute cost is lower than the other countries, to exchange their absolute production cost is higher than other products, will make the most efficient use of resources, production increase, the interests of the consumption level and save labor time. (2) The new classical trade theory. Trade between developed countries and developing countries are mainly inter-industry trade, mainly driven by factor endowments mainly intra-industry trade between developed countries, mainly caused by the scale of increasing return of specialization. (3) The enhanced new classical trade theory. New trade theory abandons the perfect competition market structure and the assumption of basic constant return, introduced the condition such as economies of the scale and imperfect competition explained after the second world wars the increasing phenomenon of intra-industry trade. (4) New classical trade theory. New classical economics is not a revolution in the economics, but in a new 
analysis framework, get rid of the consumers and producers in the new classical economics assume that absolute separation, abandons the concept of economies of scale and use specialized economic concepts, and consider the transaction cost of general equilibrium meaning [4].

Fundamentally, the enterprise application of information technology, the purpose of implementing informatization is in order to improve the core competitiveness of enterprises, to win and maintain competitive advantage and to maximize social and economic benefits. The application of information technology could improve the efficiency of the management of enterprises, reduce cost, optimize the quality, expand sales, increase profits and continuous innovation, and these are the embodiment of the competitiveness of enterprises. Enterprise as an economic organization and in its for-profit business activities engaged in by, must with the external and internal relationships, including enterprise and the society, the enterprise and the news media, the enterprise and government, enterprise and community, enterprise and competitors, enterprise and customer, enterprise and staff, etc. In their own rights and interests and social relationships, essential connotation with various ethical relationship and ethical questions, enterprise must carry on the normal production and operation activities as will have to deal with all kinds of interest relations. The figure one illustrates the mentioned principles [5].

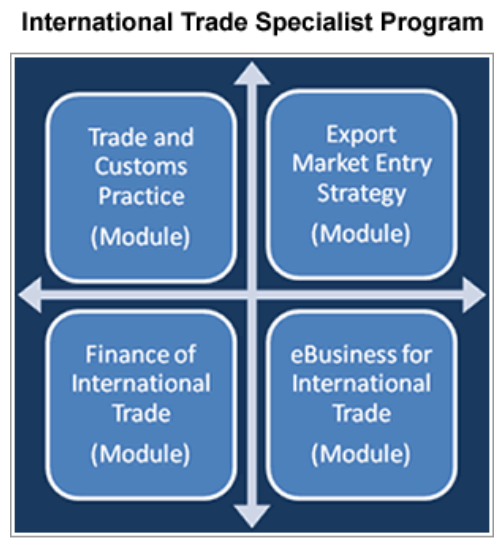

Figure 1. The Characteristics of the International Trade
In this paper, we conduct research on the logistics cost and enterprise operation efficiency with the influences on international trade. Enterprise is an aggregate of the business resources, business of the resource owner through the compromises their goal and to form a target system is the purpose of the enterprise sustainable growth. Enterprise management resources refer to the enterprises in the process of operation must have the strength of the conditions. Later sections will focus on these issues to list the proper solutions for the challenges and enhance the corresponding management steps.

\section{Our Proposed Perspective and Methodology}

The Enterprise Operation Efficiency. New classical economics on the efficiency of the research focuses on the market allocation efficiency, it defines the enterprise for the production function, that reflect relationship between the input and output, to maximize the profits are concise for the output maximum or minimum the cost under the static and dynamic under the marginal cost equals marginal revenue. New classical economics think enterprise internal structure is not important, the enterprise production always have internal efficiency and production efficiency depends on external market in the end. We can be seen from the development of these theories, enterprise efficiency depends not only on technical factors, but also on the institutional factors, for enterprise to organize the production and trading activities, including activities, and decided to the two factors is technology and system. Therefore, to improve the efficiency of enterprise must make the technology and the system constitute a system. Therefore, in reality, this control is not automatic way, but after a time limit or the collapse of the enterprise. In reality, there is, of course, by hiring a professional manager to divide some control rather than transfer control of the general situation [6]. 
The integration of enterprise is the enterprise internal with all individual genes, among them, the manager of the gene for the enterprise, gene also has the feature of genetic as it embodies in enterprise managers will experience handed down from generation to generation. Corporate gene diversity is an important reason to seek synergies, is seeking of multiple genes play a role at the same time is more than simple effect of the role of a gene, the synergistic effect can be produced in related products in the production of technical dependencies, can also be generated by enterprises in the aspects of the marketing experience and skills. Due to various technique and means on the basis of the information technology rapid development, such as strategic alliance, outsourcing, licensing, franchising, chain, network organization, virtual team and other economic behavior or phenomenon, both enterprise and the market, Coase thinks alternative to each other, even when walking or think that the elements of the market and product market substitute each other, can't for such based on modern information system justify economic behavior. New institutional economists believe that ideology is to reduce the general enterprise to provide other institutional arrangement is the most important institutional arrangements, is a person of faith, philosophy and world view, decided the people the understanding of the external environment, understanding and determine what its selection system to solve the existing problems and the system will affect the development of the enterprise again [7].

The Enterprise Operation Principles. With the rapid development of science and technology and the great changes in consumer demand, enterprises have become increasingly complex business environment, in order to improve performance, the enterprise must change the environment of market orientation and business oriented management concept properly and the integration and development.

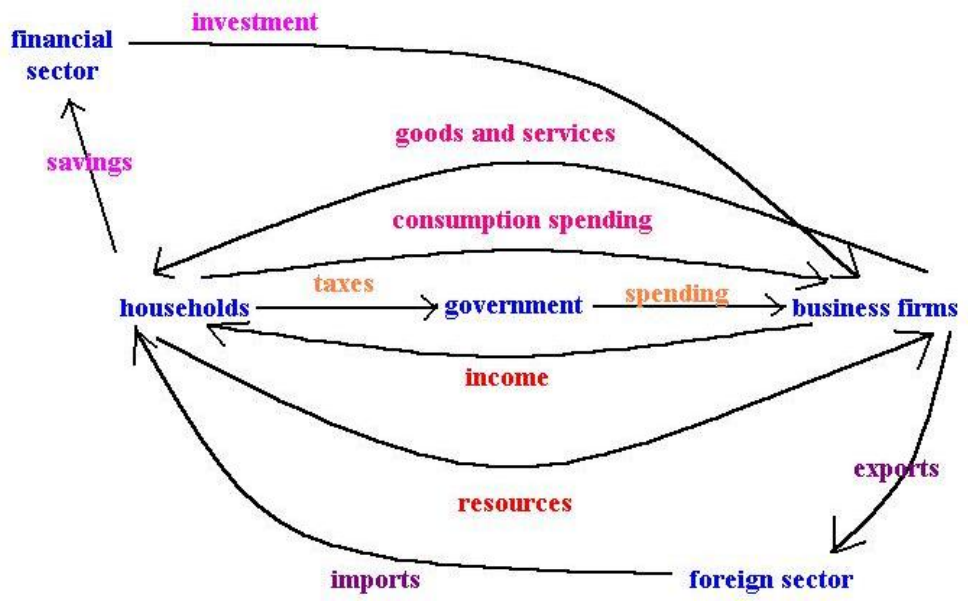

Figure 2. The Enterprise Operation and Management Flow

Enterprise culture is a kind of organizational culture, a kind of management culture. As a kind of organizational culture, she is formed in the process of establishment and development of enterprises is rooted in the consciousness of all staff in the subculture system, as a kind of management culture, she contains the value of the enterprise idea, the management idea, ways of thinking, and the behavior of the enterprise and institution, enterprise's style all the content and purpose of enterprise management. Accordingly, we should obey and follow the listed guidelines for better development.

- The sustainable development requirements. With the rapid rise of the green movement, the economic and social sustainable development has become the consensus of all countries in 
the world. Environmental pollution damage to the quality of life has caused the attention of the human, people are longing for health and safety of products, a clean environment.

- The development of information society. Because of social informatization, all kinds of the mass media to get fast development, society of all business activities of the enterprise, the management behavior, for better or worse, spread very quickly, it has greatly enhanced the strength of the supervision of public opinion to the enterprise management.

- The social support. Modern enterprises should avoid social criticism of the enterprise and enterprise in danger of being eliminated by the society must obtain the support of the society.

- Severity of laws and basic regulations. Abroad, many countries for severe punishment of the immoral behavior of the state-owned enterprises to make the enterprise to pay more and more unethical business behavior or violation of the price [8].

The International Trade. With the new development of international production, multinational companies to the international trade will increase further, while the influence of international trade, international investment and technology transfer and other economic activity will be more affected by the multinational companies. Especially the high technology and capital goods trade in multinational companies accounted for the proportion of also will more and more big, in the developed world trade in manufactured goods, due to effect of scale economy, make the same industry within the biphasic international commodity flow development soon and become the main source of trade benefits.

Participate in the international trade and business development has had a profound influence to our country economy. To participate in international trade is must master international trade development trend and influence factors, fully understand the international trading system, is the content of China's international trade system planning basic factors. Through in-depth analysis and grasp development trend and characteristics of current international trade, not only contribute to our country international trade activities of the scientific decision-making, and can make our country in a wider and wider areas and higher levels to participate in international economic cooperation and competition, to facilitate the healthy development of China's international trade.

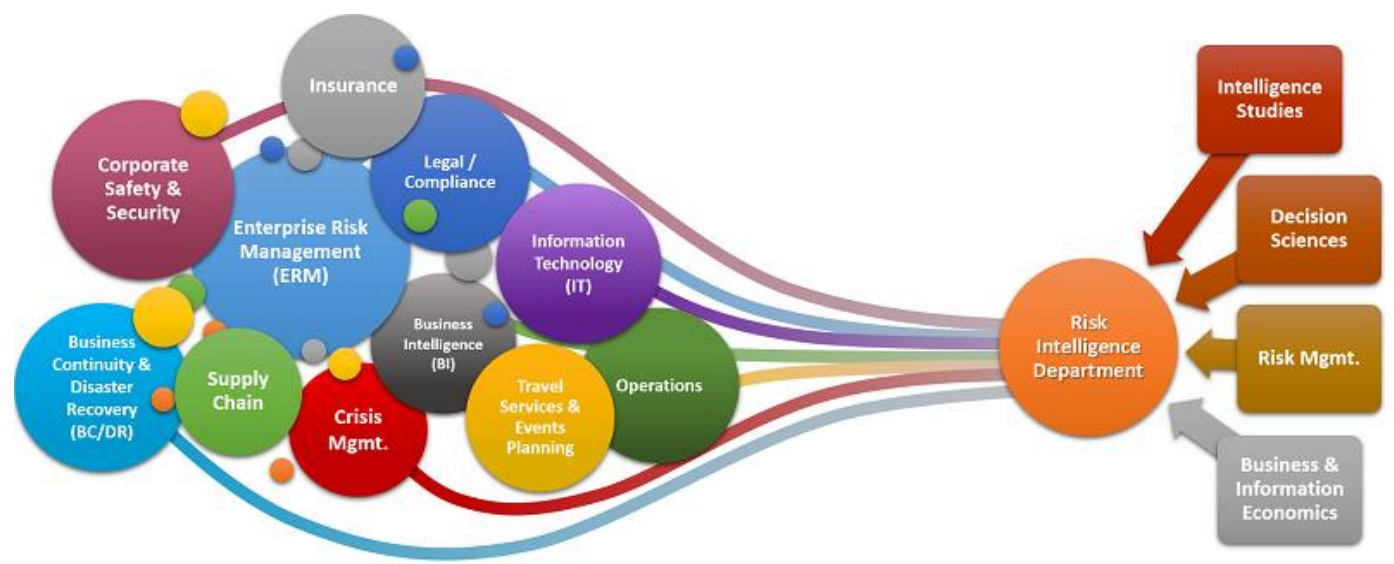

Figure 3. The Systematic Description of the International Trade 
The Logistics Cost. The range of the modern logistics cost, throughout the course of business activities, including from raw material supply to the goods will be sent to achieve all of the logistics costs incurred in the consumers' hands. Logistics is the flow of material on the physical form, namely the enterprise with the help of manpower, material resources and information on the space of physical movement, it is a kind of widespread comprehensive very strong system activity, logistics cost is to achieve what happens to the flow of material entity enterprise cost of capital is a kind of make goods more expensive and not add the cost of the commodity use value [9].

At present, the logistics cost management has caused extensive concern of our business, but due to the logistics cost management starts late, the understanding of basic logistics cost management is not enough, logistics cost management is a lack of effective method system. Therefore, we propose listed suggestions for optimization. (1) Speed up the logistics, reduce logistics cost. From the perspective of the relationship of logistics speed and liquidity requirements, in case of other conditions unchanged, the faster the speed of logistics, the less liquidity is needed, so as to reduce capital takes up, reduce the interest costs, reduce logistics costs. (2) Set up and improve the logistics enterprise informatization. Enterprises should vigorously construction of regional logistics public information platform, and the construction of logistics information network, to achieve effective transfer and sharing of the logistics information. (3) Activity-based costing is to strengthen logistics cost accounting management. To track dynamic business activities reflect the method of the cost accounting. Homework cost method based driver broke through the time of production and the labor restrictions, use a variety of related motivation for operating expenses are allocated, implementing flexible and comprehensive product cost calculation. (4) Encourage logistics enterprises bigger and stronger reduce cost. Logistics enterprises should gradually increase the intensity of and cooperation between industry and commerce enterprise, based on the market cooperation relations, the development of professional, personalized service, organic connection and promote development of the industrial chain achieve benefit-sharing.

\section{Conclusion}

In this paper, we conduct research on the logistics cost and enterprise operation efficiency with the influences on international trade. It is a set of business resources and enterprise growth is attributable to the growth of the enterprise resources, interdependence and mutual restriction between enterprise resources; Business resources are exogenous growth factors and endogenous growth factors. Internal factors of the growth of the enterprise is the growth of the business resources value-added ability, the operation and the accumulation of resources in accordance with the different features can be divided into two types of accumulation of reversible and irreversible accumulated resources. Under this basic background, we propose the novel perspectives on the issues that will be meaningful.

\section{Reference}

[1] Manova, Kalina. "Credit constraints, heterogeneous firms, and international trade." The Review of Economic Studies (2012): rds036.

[2] Wagner, Joachim. "International trade and firm performance: a survey of empirical studies since 2006." Review of World Economics 148.2 (2012): 235-267.

[3] Becker, Bo, Jinzhu Chen, and David Greenberg. "Financial development, fixed costs, and international trade." Review of corporate finance studies 2.1 (2013): 1-28. 
[4] Zhu, Zhen, et al. "The rise of China in the international trade network: a community core detection approach." PloS one 9.8 (2014): e105496.

[5] Dinopoulos, Elias, and Bulent Unel. "A simple model of quality heterogeneity and international trade." Journal of Economic Dynamics and Control 37.1 (2013): 68-83.

[6] Nagayama, Daisuke, and Masahide Horita. "A network game analysis of strategic interactions in the international trade of Russian natural gas through Ukraine and Belarus." Energy Economics 43 (2014): 89-101.

[7] Lyons, Jessica Ann, Daniel James Deans Natusch, and Chris R. Shepherd. "The harvest of freshwater turtles (Chelidae) from Papua, Indonesia, for the international pet trade." Oryx 47.02 (2013): 298-302.

[8] Tsai, Shu-Chiao. "Integrating English for specific purposes courseware into task-based learning in a context of preparing for international trade fairs." Australasian Journal of Educational Technology 29.1 (2013).

[9] Cottier, Thomas. "The Common Law of International Trade and the Future of the World Trade Organization." Journal of International Economic Law 18.1 (2015): 3-20. 